\title{
ANTIBACTERIAL EFFECT OF CHITOSAN NANOPARTICLES IN COMBINATION WITH DIODE LASER ON E.COLI BACTERIAL STRAIN
}

\author{
Doaa M. Sadony* and Hanan El-sayed Abozaid**
}

\begin{abstract}
Background /Aim: The antibacterial effect was assessed by dead/live technique by conjunction between chitosan nanoparticle and diode laser (970nm), were chitosan has an excellent biocompatibility with tissues; save to human with no side effect; excellent bioactivity effect; chelation ability, good absorptive capacity, and antimicrobial activity regarding gram-positive and gram-negative bacteria. The studies have showed chitosan mechanism action related to the films formed around the cell which prevents nutrients absorption. Other res,earch indicates that, using laser radiation in the treatment of dental hard tissue and helping in the root canal formation, the addition effects of diode laser is bacteriostatic effect on bacterial strains present in root canal. The laser radiation was transmitted through quartz optical fibers, which could introducing laser light inside root canal, around canal curvatures and irregularities more easily. Throughout this review the aim of our study is present and discuss the antimicrobial activity of chitosan nanoparticles in combination with diode laser against oral bacteria especially the E.coli and aimed for developing commercial products such as an irrigant solution for root canal. The aim of this study was to estimate the ability of 970-nm diode laser to disinfection in combination with chitosan nanoparticlesagainst negative charged E.coli bacterial strain
\end{abstract}

Materials and methods: The root canals of 40 extracted single-rooted incisors teeth were prepared by rotary system. After crown removal, the roots were autoclaved. The teeth were inoculated with E. coli suspension for two weeks. The samples were divided into four groups $(\mathrm{n}=10)$. The samples of the first group $\mathrm{G} 1(\mathrm{n}=10)$ were inoculated with bacteria only as control group, the second group G2 $(n=10)$ were inoculated with bacteria \& chitosan, the group will be divided in 2 subgroup according to the time of incubation (60 seconds, 90 seconds) ( $\mathrm{n}=5$ ). The third group G3 were inoculated with bacteria and treated with a 970-nm diode laser, the group will be divided in 2 subgroup according to the time of laser irradiation (60 seconds, and 90 seconds) $(n=5)$. The fourth group $\mathrm{G} 4(\mathrm{n}=10)$ were inoculated with bacteria \&chitosan and treated with diode laser, the group will be divided in 2 subgroup according to the time of laser irradiation (60 seconds, and 90 seconds) $(\mathrm{n}=5)$. Bacterial samples were taken from the root canals and the cultivation.

\footnotetext{
* Researcher in Restorative and Dental materials Department (National Research Centre, Giza, Egypt).

** Lecturer of Clinical Pathology, Faculty of Medicine (Helwan University, Cairo, Egypt).
} 
was carried out. The standard deviation of colony-forming units (CFU) for each specimen were measured to compare the reduction in $\mathrm{CFU}$ in each group.

Results: low mean CFU/mL is recorded in Group2 (chitosan with laser) followed by Group3 (chitosan) and Group 4 (laser), respectively. The difference in CFU/mL between the three groups is statistical significant $(\mathrm{P} \leq 0.05)$.

Conclusion: The results of this research show that 970-nm diode laser in combination with chitosan nanoparticles could be used as a complementary disinfection device in root canal treatment and ability to increase the success rate in endodontic therapy.

\section{INTRODUCTION}

In Endodontics, complete removal of any bacteria, micro-organisms present in root canal is essential step for full successful root canal treatment. The contamination of the root canals with different bacterial strains or present of bacterial remnants of necrotic soft tissue are considered one of the main reasons for failure in root canal treatment ${ }^{(1)}$. The complete removal of persisting microorganisms in remote areas of the dentinal tube is a major aim in today's treatment regimens and is important for the long-term preservation of the root canal treated tooth.Studies have shown that microorganisms present in failed root canal cases are far from those present in infected root canals before endodontic treatment ${ }^{(4)}$. E. coli is a facultative anaerobic gram negative bacteria, which is present in oral flora , in root canal infections and is also related to the failure of root canal treatment ${ }^{(3)}$. They form intra and extra radicular biofilms, which are difficult to remove and they cause reinfection ${ }^{(5,6)}$. No individual irrigant or instrumentation technique is capable of completely disinfecting the root canal space. However, combining between nanoparticles chitosan and diode laser can possibly have a strong synergistic effect. Lasers have the potential to be used in such approaches. Different laser systems have been investigated for their role in root canal disinfection following instrumentation, either alone, or in association with other materials ${ }^{(7)}$, as Chitosan which exhibits antibacterial activity against various bacteria $^{(22)}$.

\section{MATERIALS AND METHODS}

\section{Sample preparation}

Forty extracted single-rooted incisors teeth were stored in $5.2 \% \mathrm{NaOCl}$ solution for $30 \mathrm{~min}$ to remove any residues and left in saline solution until the procedure began. The crowns were removed at the cemento-enamel junction using high-speed diamond disk. Access opening was done. \#10 K-file (Dentsply-Maillefer) was introduced into each canal until it appeared at the apical foramen. The working length was established by subtracting $0.5 \mathrm{~mm}$ from this length. The canals were shaped using stepback technique to \#40 K-file (Denstply-Mailer). Irrigating solution used after each instrument was $5 \mathrm{~mL}$ of $2.5 \%$ sodium hypochlorite. The coronal third of the root canals was flared with \#2, \#3 and \#4 Gates Glidden drills. The teeth were allowed to air-dry overnight at room temperature and apical foramen was sealed externally with coats of clear nail polish. The teeth underwent sterilization in 121 ${ }^{\circ} \mathrm{C}$ autoclave for $15 \mathrm{~min}$ at $15 \mathrm{lbs}$ pressure ${ }^{(24)}$. The samples divided in to 4 groups; G1 control group bacterial strain only $(\mathrm{n}=10), \mathrm{G} 2$ bacterial strain and chitosan $(n=10)$ the group will be divided in 2 subgroup according to the time of incubation (60seconds, and 90 seconds) (n=5), G3 bacterial strain and laser treatment $(n=10)$, the group will be divided in 2 subgroup according to the time of laser irradiation (60seconds, and 90 seconds) $(n=5)$, and $\mathrm{G} 4$ bacterial strain with combination between chitosan and laser treatment $(\mathrm{n}=10)$,the group will 
be divided in 2 subgroup according to the time of laser irradiation (60 seconds, and 90 seconds) $(n=5)$.

\section{Preparation the medium for E. coli}

The strains of microorganisms used for this study were standard strains of E. coli ATCC 25922, which were sub-cultured in UTI HI chrome agar plate (selective medium) and was incubated at $37^{\circ} \mathrm{C}$ for $24 \mathrm{~h}$. A pure, single E. coli colony was isolated from the same cultured plate and Gram's staining was done to confirm its growth, which was observed under microscope and then inoculated with a blood agar. The BHI broth was incubated at $37^{\circ} \mathrm{C}$ for a $24-\mathrm{h}$ period and checked for bacterial growth by changes in turbidity. A drop of BHI containing E. coli was placed into saline solution and checked for correct bacterial concentration with a spectrophotometer. The density of the bacterial suspension is standardized by comparing the broth at a density equivalent to the barium sulphate standard of 0.5 McFarland units, which is equivalent to 1.5 $\times 108$ colony forming units per millilitre (CFU/ $\mathrm{mL}$ ). Before irradiation, a micropipette with a sterile needle was used to inoculate the canals with $10 \mathrm{~mL}$ of the bacterial suspension in nutrient broth. The teeth were randomly assigned to three groups and placed into nutrient broth containing bacterial suspension ${ }^{(24)}$.

\section{Synthesis of chitosan nanoparticles}

The CNPs were synthesized based on a previously published protocol using an ionic gelation method. ${ }^{(15)}$ Briefly, the chitosan powder (Polymar Ciência e Nutrição S/A, Fortaleza, Brazil) was dissolved in $1 \%$ acetic acid under magnetic stirring at room temperature. Next, $1 \mathrm{mg} / \mathrm{mL}$ sodium tripoly-phosphate solution (Sigma-Aldrich Chemical Co., St. Louis, MO, USA) was added into the chitosan solution. The preparations were mixed with a Polytron homogenizer (PT-3000, Brinkman Instruments, Rexdale, ON, Canada) at 5,000 rpm with drop-wise addition of the tripoly-phosphate solution, thus achieving a final CNPs concentration of $1.29 \mathrm{mg} / \mathrm{mL}$. The zone of opalescent suspension was visible with the formation of the nanoparticles, and the solution was further examined for nanoparticle characterization. The concentration of tri-polyphosphate solution in the final solution was $0.3-0.6 \mathrm{mg} / \mathrm{mL}$. The range of the nanoparticles' size was $85-221 \mathrm{~nm}^{(23,27)}$.

\section{Laser procedure}

Specimens of G3 and G4 were treated with diode laser (A gallium-aluminium-arsenide (GaAlAS) diode laser Siro-Laser Advance class IIIb SIRONA the Dental Company, Germany) at wavelength $970 \mathrm{~nm} \&$ power 1.5 Watt. It provided through a flexible $220-\mu \mathrm{m}$ optic fiber diameter with a straight hand-piece in continuous mode at circular movement. Diode Laser irradiation applied at different exposure times (60 second, and 90 seconds respectively).After laser irradiation, the teeth were placed in vials, which contained $2 \mathrm{~mL}$ of the nutrient brothfor bacterial account ${ }^{(25)}$.

\section{Bacteriological analysis}

The vials were incubated at $37^{\circ} \mathrm{C}$ for $24 \mathrm{~h}$. The vials were checked for turbidity after $24 \mathrm{~h}$ incubation. Dilution of the sample was maintained at 103 . Overall $6 \mathrm{~mL}$ of broth, in duplicate, from all the samples together was collected and seeded on a Petri dish containing UTI blood agar in order to count the CFUs. Incubation lasted $48 \mathrm{~h}$ at $37^{\circ} \mathrm{C}$. Grown colonies were seen in all groups and were identified by standard methods ${ }^{(25)}$.

\section{RESULTS}

The mean and standard deviation values were calculated, whereviable counts of antibacterial activity were transformed to their log 10 values. Data were explored for normality using KolmogorovSmirnov and Shapiro-Wilk tests and showed parametric (normal) distribution. 
One-way ANOVA followed by Tukey post hoc test was used to compare between more than two groups in non-related samples. Paired t-test was used to compare between two groups in related samples. The significance level was set at $\mathrm{P} \leq 0.05$. Statistical analysis was performed with $\mathrm{IBM}^{\circledR}$ SPSS ${ }^{\circledR}$ Statistics Version 20 for Windows.

The mean and standard deviation $( \pm \mathrm{SD})$ values were calculated in each group as following:

\section{A) Effect of time on antibacterial activity}

\section{1) Control group}

There was a statistically significant difference between (60 seconds) and (90 seconds) where $(\mathrm{p}<0.001)$.The highest mean value was found in $(60$ seconds) while the least mean value was found in (90 seconds).

\section{2) Chitosan group}

There was a statistically significant difference between (60 seconds) and (90 seconds) where $(\mathrm{p}=0.034)$.The highest mean value was found in $(60$ seconds) while the least mean value was found in (90 seconds).

\section{3) Laser group}

There was a statistically significant difference between (60 seconds) and (90 seconds) where $(\mathrm{p}=0.025)$.The highest mean value was found in $(90$ seconds) while the least mean value was found in (60 seconds).

\section{4) Both group}

There was a statistically significant difference between (60 seconds) and (90 seconds) where $(\mathrm{p}<0.001)$. The highest mean value was found in (90 seconds) while the least mean value was found in (60 seconds)

\section{B) Effect of groups on antibacterial activity}

\section{1) 60 seconds group}

There was a statistically significant difference between (Control), (Chitosan), (Laser) and (Both) where $(\mathrm{p}<0.001)$. A statistically significant difference was found between (Control) and each of (Chitosan), (Laser) and (Both) where ( $\mathrm{p}<0.001)$. Also, a statistically significant difference was found between (Chitosan) and each of (Laser) and (Both) where $(\mathrm{p}<0.001)$. A statistically significant

TABLE (1): The mean, standard deviation $( \pm \mathrm{SD})$ values of antibacterial activity of different groups.

\begin{tabular}{|c|c|c|c|c|c|}
\hline \multirow[t]{3}{*}{ Variables } & \multicolumn{5}{|c|}{ Antibacterial activity } \\
\hline & \multicolumn{2}{|c|}{60 seconds } & \multicolumn{2}{|c|}{90 seconds } & \multirow[t]{2}{*}{ P-value } \\
\hline & Mean & SD & Mean & $\mathrm{SD}$ & \\
\hline Control & 5.18 & 0.00 & 4.25 & 0.00 & $<0.001 *$ \\
\hline Chitosan & 4.84 & 0.02 & 4.78 & 0.05 & $0.034 *$ \\
\hline Laser & 5.03 & 0.02 & 5.08 & 0.02 & $0.025^{*}$ \\
\hline Both & 0.00 & 0.00 & 4.51 & 0.13 & $<0.001^{*}$ \\
\hline$P$-value & $<0.001 *$ & $<0.001 *$ & $<0.001 *$ & $<0.001 *$ & \\
\hline
\end{tabular}


difference was found between (Laser) and (Both) where $(\mathrm{p}<0.001)$.

The highest mean value was found in (Control) followed by (Laser) and (Chitosan) while the least mean value was found in (Both).

\section{2) 90 seconds group}

There was a statistically significant difference between (Control), (Chitosan), (Laser) and (Both) where $(\mathrm{p}<0.001)$. A statistically significant difference was found between (Control) and each of (Chitosan), (Laser) and (Both) where ( $\mathrm{p}<0.001)$. Also, a statistically significant difference was found between (Chitosan) and each of (Laser) and (Both) where $(\mathrm{p}<0.001)$. A statistically significant difference was found between (Laser) and (Both) where $(p<0.001)$.

The highest mean value was in (Laser) followed by (Chitosan) and (Both) while the least mean value was found in (Control).

\section{DISCUSSION}

Recently, different laser systems are used in dentistry especially endodontic field, which are effective for root canal disinfection. The diode laser is a compact device and now used in all fields of dentistry ${ }^{(8,9)}$. Moritz et al, introduced use of diode laser for root canal disinfection ${ }^{(10)}$. The antibacterial effect of diode occur in our study at the laser group only (at 60 seconds) in agreement with Asnaashari and Safavi ${ }^{(21)}$, which show antibacterial effect on bacterial strain of E.coli.

E. coli is a negative microorganism and show slight resistant to high temperatures ${ }^{(14)}$ frequently found in cases of therapy resistant infection. E. coli was used in this study in order to discuss the effect of the laser heat in combination with chitosan nanopaticles on this bacteria. An antibacterial effect is depend on union between chitosan and bacteria DNA, then interfering with mRNA and protein synthesis of bacterial cell, which allow entry of the chitosan into the cell ${ }^{(12)}$.
It is supposed that chitosan nanoparticles work on the cell wall of the bacteria causing change in the electric potential of the cell membrane ${ }^{(14)}$. According to Kong et al ${ }^{(15)}$, in addition to antibacterial activity of chitosan, it has explained the low toxicity. This occur in our study, which chitosan nanoparticles has antibacterial effect on E.coli bacterial strain, the antimicrobial action of the chitosan depend on: 1. Essentinal characters of the chitosan (positive charge, low molecular weight, chelation capacity, hydrophobic and hydrophilic characteristics); 2. Microbial factors (microbial species); 3. Environmental factors ( $\mathrm{pH}$, temperature, and time). The authors tell that the amino groups of the chitosan become in contact with cell component and bind to anionic groups of the bacteria, resulting in the bacterial cell agglutination and inhibition of cell growth causing cell death ${ }^{(16)}$. When testing the relation between bactericidal effect of the chitosan nanoparticles and the characteristics of bacterial cell wall, Chung et al ${ }^{(14)}$, chitosan showed an excellent bactericidal and bacteriostatic action for Gram-negative than Gram-positive bacteria due the bacterial cell wall in gram negative bacteria contain phospholipids and carboxylic acids, which the chitosan nanoparticals enters more easily in gram-negative bacteria, causing changing in the metabolism of microorganism lead to cell death. Tsai and $\mathrm{Su}{ }^{(17)}$ and Zheng and Zhu ${ }^{(18)}$ have proved that the antibacterial effect of the chitosan is directly related with the absorption of the polysaccharide to the bacterium, which will cause changes in the cellular wall structure to allow cellular membrane permeability more easily and cell death at end. This in agreement with our study which chitosan nanoparticles group show antibacterial effect at 30 seconds ${ }^{(11,13)}$.

One of the most important properties of chitosan nanoparticles is the ability to transform light into heat under diode laser irradiation as gold nanoparticles ${ }^{(19)}$. This property is historic because it used to causenano-photo-thermal effects in order to damagethe bacteria, by increase time oflaserradiation 
heat by diode laser device, start to replicate the number of bacteria still present live, which in agree with our study in group of combination between chitosan nanoparticles and diode laser at 90 seconds.

In other study ${ }^{(26)}$ the development of a photonto-thermal against nano-system and exposure of chitosan nanoparticlesto laser irradiation cause a rapid increase in temperature of media. Laserexcited chitosan nanoparticles to cause photothermal lysis of the bacteria, and determining their thermal and optical properties. Chitosan nanoparticles proved to absorb laser radiation (970 nm, 1.5 W, continuous mode) to a greater extent, and temperature was significantly higher, When induced by continuous wave laser irradiation at 90 seconds, these nanoparticles were able to increase the temperature to above $60^{\circ} \mathrm{C}$ in all media; so, E. coli cell lysis wasn't obtained by exposure of the bacteria to laser irradiation but replication was occur,this in agreement with Kim et al ${ }^{(20)}$.

\section{CONCLUSION}

The combination between diode laser and chitosan nanoparticles show high antibacterial effect at $60 \mathrm{sec}$. (zero growth) than the other groups, due to bactericidal effect of both diode laser radiation and nanoparticles chitosan on E.coli bacterial strain.

\section{REFERENCES}

1. Stamford T., Santos E., Tenório P. and Sampaio F. Chitosan as an oral antimicrobial agentagainst microbial pathogens. communicating current research and technological advances. 2011; 1: 542-550.

2. Hibst R., Graser R., Udart M., and Stock K. Mechanism of high-power NIR laser bacteria Inactivation. J. Biophoton. 2010; 6: 296-303.

3. Stabholz A., Sahar-Helft S., and Moshonov J. Clinical significance of dental root canal microflora. J Dent 1996; 24:47-55

4. Haapasalo M. Bacteroides spp. in dental root canal infections. Endod Dent Traumatol 1989; 5:1-10.
5. Spratt D., Pratten J., Wilson M., and Gulabivala K. An in vitro evaluation of the antimicrobial efficacy of irrigants on biofilms of root canal isolates. IntEndod J. 2001; 34:300-7.

6. Berutti E., Marini R., and Angeretti A. Penetration ability of different irrigants into dentinal tubules. J Endod. 1997; 23:725-7.

7. Moritz A., Gutknecht N., Goharkhay K., Schoop U., Wernisch J., andSperr W. In vitro irradiation of infected root canals with a diode laser: results of microbiologic, infrared spectrometric, and stain penetration examinations. Quintessence Int. 1997; 28(3):205-09.

8. Pearson G., and Schuekert K. The role of lasers in dentistry: Present and future. Dent Update. 2003; 74:838-43.

9. Moritz A., Gutknecht N., Goharkhay K., Schoop U., Wernisch J., and Sperr W. In vitro irradiation of infected root canals with a diode laser: Results of microbiological examinations. Quintessence Int. 1997; 28:205-9.

10. Mortiz A., Doertbudak O., Gutknecht N., Goharkhay K., Schoop G., and Sperr U. Nd: YAG laser irradiation of infected root canals in combination with microbiological examinations. J Am Dent Assoc 1997; 128:1525-30.

11. Goy R., De Britto D., Assis O. A review of the antimicrobial activity of chitosan. Polimeros; Ciência e Tecnologia.2009; 19: $241-247$

12. Tsai G. and Wen-Huey S. Antibacterial Activity of Shrimp Chitosan against Escherichia coli. Journal of Food Protection. 1999; 62(3): 239-243.

13. Carvalho G., Stamford T., Santos E., Tenório P.and Sampaio F. Chitosan as an oral antimicrobial agent. Science against microbial pathogens: communicating current research and technological advances.2011:542-550.

14. Yadav AV, Bhise .B. Chitosan: a potencial biomaterial effective against typhoid. Cur. Sci.(2004), 87(9): 11761178 .

15. Chung Y., Su Y., Chen C., Jia G., Wang H., WU J., LIN J. Relationship between antibacterial activity of chitosan and surface characteristics of cell wall. Acta Pharmacol Sin. 2004; 25(7):932-936.

16. Kong M., Chen X., Xing K., and Park H. Antimicrobial properties of chitosan and mode of action: A state of the art review.International J. Food Microbiology. 2010; 144: 51-63.

17. Goy R., Britto D., and Assis O. A Review of the Antimicrobial Activity of Chitosan. Polímeros: Ciência e Tecnologia. (2009), 19(3): 241-247. 
18. Ikinci G., Senel S., Akincibay H., Kas S., Ercis S., Wilson C., and Hincal A. Effect of chitosan on a periodontal pathogen Porphyromonasgingivalis. Int. J. Pharm. (2002), 235:121-7.

19. Zhao Y., Tian Y., Cui Y., Liu W., Ma W., and Jiang X. Small molecule-capped gold nanoparticles as potent antibacterial agents that target gram-negative bacteria. J Am Chem Soc. 2010; 32(35):12349-12356.

20. Kim C., Yi D., Kim P., Lee W., and Kim M. Rapid photothermal lysis of the pathogenic bacteria, Escherichia coli using synthesis of gold nanorods. J Nanosci Nanotechnol. 2009; 9(5):2841-2845.

21. Asnaashari M. and Safavi N. Disinfection of Contaminated Canals by Different Laser Wavelengths, while Performing Root Canal Therapy. Journal of Lasers in Medical Sciences.2013; 4 (1):8-16.

22. Tsai G. and Su W. Antibacterial Activity of Shrimp Chitosan against Escherichia coli .Journal of Food Protection, 1999; 62(3): 239-243

23. Carpio-Perochena A., Bramante C., Duarte M., Moura M., Aouada F. and Kishen A. Chelating and antibacterial properties of chitosan nanoparticles on dentin. Restor Dent ndod. 2015; 40(3):195-201.

24. Kaiwar A., Usha H., Meena N., Ashwini P., and Murthy C. The efficiency of root canal disinfection using a diode laser: In vitro study. Indian J Dent Res. 2013; 24 (1):14-8.

25. Jyotsna S., Raju R., Patil J., Singh T., Bhutani N., Kamishetty S., and Ghatole K. Effect of Diode Laser on Bacteria Beyond the Apex in Relation to the Size of the Apical Preparation - An In-Vitro Study. J ClinDiagn Res. 2016; 10(5): ZC63-ZC65.

26. Mocan L., Tabaran F., Mocan T., Pop T., Mosteanu O., Agoston-Coldea L., Matea C., Gonciar D., Zdrehus C., and Iancu C. Laser thermal ablation of multidrug-resistant bacteria using functionalized gold nanoparticles. Int $\mathrm{J}$ Nanomedicine. 2017; 12: 2255-2263.

27. Avadi M., Sadeghi A., Tahzibi, A., Bayati, K., Pouladzadeh M., and Zohuriaan-Mehr M. Diethylmethyl chitosan as antimicrobial agent: synthesis, characterization and antibacterial effects. Europ. Pol. J. 2004; 40:1355-1362. 